\title{
Raisin allergy in an 8 year old patient
}

\author{
S Chibuluzo ${ }^{1 *}$, T Pitt $^{2}$ \\ From Canadian Society of Allergy and Clinical Immunology Annual Scientific Meeting 2014 \\ Ottawa, ON, Canada. 23-26 October 2014
}

\section{Introduction}

Raisin allergy is uncommon despite worldwide cultivation of grapes, which belong to the Vitis vinifera species of the Vitaceae family. There have only been rare reports of anaphylaxis in adults related to the consumption of grapes, wine or other grape products, mostly in Europe [1-4]. In children, even fewer case reports to grape exist [5]. We report an 8-year-old patient who developed itching of the mouth and nausea within a few minutes of ingestion of fresh raisin on repeated occasions. Interestingly, he tolerates grapes.

\section{Methods}

Skin prick testing (via prick-by-prick method) to fresh seedless raisin, birch pollen, a mixture of trees, grass, and ragweed was performed on the patient. Skin prick testing to fresh seedless raisin (via prick-by-prick method) was also performed on a non-atopic healthy control.

\section{Results}

Skin testing was positive to fresh seedless raisins $(\sim 5 \mathrm{~mm})$ in our 8-year-old patient and negative in the healthy control. The patient was advised to avoid raisins and to carry an Epinephrine auto-injector. He was encouraged to continue to consume fresh grapes.

\section{Conclusions}

We report one of the first cases of presumed allergy to fresh raisin, in the absence of pollen food syndrome, in a North American patient who currently tolerates fresh grapes. Further research is required to determine the etiology and prevalence of this allergy. We propose that a chemical component used in the processing of raisins may be responsible for this allergy.

'St. George's University, School of Medicine, Grenada, West Indies Full list of author information is available at the end of the article

\section{Consent}

Written informed consent was obtained from the patient for publication of this abstract and any accompanying images. A copy of the written consent is available for review by the Editor of this journal.

\section{Authors' details}

${ }^{1}$ St. George's University, School of Medicine, Grenada, West Indies. ${ }^{2}$ Humber River Hospital, Toronto, Ontario, Canada.

Published: 18 December 2014

\section{References}

1. Alcoceba Borràs E, Botey Faraudo E, Gaig Jané P, Bartolomé Zavala B: Alcohol-induced anaphylaxis to grapes. Allergol Immunopathol (Madr) 2007, 35(4):159-61

2. Kalogeromitros DC, Makris MP, Gregoriou SG, Mousatou VG, Lyris NG, Tarassi KE, Papasteriades CA: Grape anaphylaxis: a study of 11 adult onset cases. Allergy Asthma Proc 2005, 26(1):53-8.

3. Caiaffa MF, Tursi A, Macchia L: Grape anaphylaxis. J Investig Allergol Clin Immunol 2003, 13(3):211-2.

4. Senna G, Mistrello G, Roncarolo D, Crivellaro M, Bonadonna P, Schiappoli M, Passalacqua G: Exercise-induced anaphylaxis to grape. Allergy 2001, 56(12):1235-6.

5. Cardinale F, Berardi M, Chinellato I, Damiani E, Nettis E: A child with anaphylaxis to grapes without reaction to grape seed oil. Allergy 2010, 65(6):800-1.

doi:10.1186/1710-1492-10-S2-A6

Cite this article as: Chibuluzo and Pitt: Raisin allergy in an 8 year old patient. Allergy, Asthma and Clinical Immunology 2014 10(Suppl 2):A6.

\section{Submit your next manuscript to BioMed Central} and take full advantage of:

- Convenient online submission

- Thorough peer review

- No space constraints or color figure charges

- Immediate publication on acceptance

- Inclusion in PubMed, CAS, Scopus and Google Scholar

- Research which is freely available for redistribution

Submit your manuscript at www.biomedcentral.com/submit
() Biomed Central

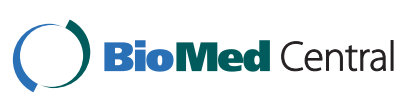

